\title{
TASAWUF DAN RESOLUSI MORAL: STUDI TERHADAP IMPLIKASI AJARAN TASAWUF DALAM MENGATASI DEGRADASI MORAL
}

\author{
Oleh: \\ Muhammad Amin \\ muhammadamin uin@radenfatah.ac.id
}

\begin{abstract}
Moral degradation is a complicated problem to solve. This applies to all nations in the world. Because, moral damage to society in a country can result in the destruction of a nation. For this reason, the urgency to study strategies needs to be done in overcoming this. The conclusion of this paper is: that the teachings in Sufism can be one of the resolutions in overcoming moral degradation. The teaching is implemented in several stages, namely takhalli, tahalli, and tajalli.
\end{abstract}

Keywords: Moral Degradation, Moral Resolution, Sufism

\begin{abstract}
Abstrak
Degradasi moral menjadi masalah yang rumit untuk diselesaikan. Hal ini berlaku bagi semua bangsa yang ada di dunia. Karena, kerusakan moral pada masyarakat di suatu negara dapat mengakibatkan hancurnya suatu bangsa. Untuk itulah urgensi dikajinya strategi yang perlu dilakukan dalam mengatasi hal tersebut. Kesimpulan tulisan ini, adalah: bahwa ajaran-ajaran dalam tasawuf dapat menjadi salah satu resolusi dalam mengatasi degradasi moral. Ajaran tersebut diimplementasikan dalah beberapa tahapan, yaitu takhalli, tahalli, dan tajalli.
\end{abstract}

Kata kunci: Degradasi moral, Resolusi Moral, Tasawuf

\section{A. Pendahuluan}

Kajian tentang degradasi moral telah banyak dibahas, salah satunya filosuf Yunani, seperti Socrates, Plato, dan Aristoteles. Mereka telah memperbincangkan tentang moral dan moralitas dalam hubungannya dengan kehidupan manusia pada umumnya. Menurut mereka, moralitas bersifat naturalistik, rasionalistik, dan objektivistik.

Moralitas bersifat naturalistik, dalam arti bahwa moralitas dipandang sebagai bagian dari dunia alami dan umat manusia dipandang sebagai sangat peduli akan pencapaian hidup yang baik, di dunia saat ini maupun di dunia yang akan datang. 
Moralitas juga bersiafat rasionalistik dan objektivistik, dalam arti bahwa mereka percaya dan meyakini akan adanya wujud kebenaran yang objektif. Selain itu, bahwa akal budi merupakan satu-satunya sumber pengetahuan yang benar dari kebenaran itu. ${ }^{1}$ Dalam filsafat akal atau logika merupakan sumber kebenaran, serta dengan akal manusia bisa memperoleh pengetahuan. Hal ini merupakan cikal bakal bermunculanlah para filosof.

Munculnya pemikiran para filosuf Yunani yang mengkaji tentang moral diantaranya Augustinus dan Thomas Aqinas, menandai alam pikiran tentang moral Abad Pertengahan yang berorientasi rohaniah dan objektivistik. Karya-karya Aurelius Augustinus (354-430 M) Melalui bukunya yang berjudul Civitate Dei, di samping membicarakan hubungan antara negara dan moral, ia juga bercita-cita untuk mendirikan negara yang berdasarkan moral-agama. Dikatakannya bahwa cerita terusirnya Adam dari surga karena pengaruh syaitan. Selain itu, terjadinya perkelahian antara kedua putera Adam yang berujung pembunuhan, merupakan salah satu gambaran dari perjuangan antara negara yang bermoral baik (Negara Tuhan) dengan negara yang bermoral jahat (Negara Syaitan).

Prinsip Augustinus inilah yang dipakai oleh golongan Katholik untuk mendirikan Negara Gereja yang dipimpin oleh seorang Sri Paus. Prinsip ini kemudian diperkuat oleh Thomas Aquinas (122-1274) dengan dua bukunya yang berjudul Summa Theologiae dan Summa Contra Gentiles. Dunia dalam versi Thomisme merupakan suatu keseluruhan yang harmonis yang dicipta dan dijelmakan oleh Tuhan Yang Mahakasih dan Mahabijak. Manusia dan alam, moralitas dan keselamatan, iman dan penalaran, itu semua berada dalam kesatuan ilahi. $^{2}$

Di dunia Islam, antara lain muncul seorang al-Gazali (1058-1111), dengan teorinya yang menggabungkan negara dengan moral, yang dinamakannya kemudian dengan Siyasatul Akhlaq atau Negara Moral. Pendapat Al-Gazali memiliki kemiripan dengan pendapat para tokoh Kristen di atas, namun demikian tidaklah berarti bahwa al-Gazali menghendaki Negara Agama. Al-Gazali hanya menghendaki agar unsur agama harus dipertahankan dalam negara.

\footnotetext{
${ }^{1}$ William M. Kurtines dan Jacob L. Gerwitz, Moralitas, Perilaku Moral, dan Perkembangan Moral, Jakarta: UI Press, 1992, hal.14-15.

${ }^{2}$ William M. Kurtines dan Jacob L. Gerwitz.....hlm. 19
} 
Bagi al-Gazali, negara dan moral tidak lagi merupakan dua hal yang terpisah, tetapi keduanya harus disatu-padukan, menjadi satu badan yang kompak. Menurutnya, negara yang tidak mempunyai moral berarti keruntuhan; dan sebaliknya moral yang tidak sejalan dengan negara adalah kelumpuhan. Seraya mengutip sabda Nabi Muhammad yang berbunyi: "Sesungguhnya aku diutus adalah untuk menyempurnakan akhlak yang utama".

Munculnya pendapat dan tulisan yang mengkaitkan antara negara dan moral, tentu saja memiliki latar belakangnya sendiri. Bencana besar akan menimpa suatu bangsa atau umat, demikian dikatakan al-Gazali, kala bangsa atau umat itu dihinggapi oleh suatu penyakit yang berbahaya, yaitu krisis moral. Dalam waktu sekejap, penyakit ini akan mengancam keutuhan suatu bangsa atau umat. Krisis moral dengan sendirinya akan menyebabkan terjadinya krisis yang bersifat multi kompleks, yaitu krisis di semua bidang kehidupan.

Untuk ini al-Gazali menyebut adanya tiga akibat yang disebabkan krisis moral ini: Dalam bidang politik, ia akan menimbulkan penyalahgunaan kekuasaan. Para pejabat negara mempergunakan kekuasaannya secara salah. Korupsi, kolusi, dan nepotisme (KKN) merajalela. Kekuasaan dipergunakan untuk memenuhi nafsu serakah individu dan kelompoknya. Jika pihak atasan sudah berbuat demikian, maka para pegawai di tingkat bawah mengambil teladan atas perilaku atasannya itu. Apabila demikian, maka pemerintahan merupakan suatu alat pengrusak di tangan orang-orang yang jahat dan rakus.

Tidak pula kurang dahsyatnya, adalah bencana krisis moral dalam bidang ekonomi. Kerusakan dalam bidang ini akibatnya akan mengancam kepentingan hidup orang banyak. Krisis ini lebih dahsyat akibatnya daripada sekedar depresi ekonomi. Wabah korupsi yang sudah demikian kronis, akan berakibat pada kebangkrutan dan kehancuran negara. Dengan demikian, perlu sesegera mungkin untuk mengingatkan dan menyadarkan para pejabat negara dari budaya korup ini. Akibat dari krisis moral ini secara keseluruhan adalah munculnya budaya rakus. Mereka yang telah mengidap penyakit ini akan menggunakan segala cara, menghalalkan segala cara; mereka hanya memperturutkan nafsu hewaninya, demi tujuan yang diinginkannya. Freud mengatakan bahwa pangkal dari berbagai macam 
penyakit yang mengganggu manusia berawal dari pertentangan di dalam hawa nafsu (sexueel conflict). Dalam bahasa al-Qur'an dikatakan: "sesungguhnya nafsu cenderung selalu mengarahkan pada kesesatan" (Q.S. Yusuf (12):53).

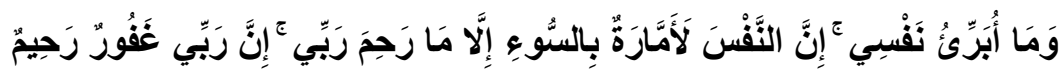

Artinya: Dan aku tidak membebaskan diriku (dari kesalahan), karena sesungguhnya nafsu itu selalu menyuruh kepada kejahatan, kecuali nafsu yang diberi rahmat oleh Tuhanku. Sesungguhnya Tuhanku Maha Pengampun lagi Maha Penyanyang.

Dapat dipahami bahwa apabila manusia menuruti hawa nafsunya akan mengakibatkan perbuatan yang tidak bermoral, apabila seorang pejabat dia akan korupsi atau menyalahkan gunakan jabatannya untuk memenuhi nafsunya. Hal ini dapat menyebabkan kehancuran suatu bangsa.

Penulis melihat kondisi moral indonesia pada saat ini sangat memprihatinkan, tindakan a moral tidak hanya terjadi dalam lingkungan rakyat kecil, namun juga terjadi pada para pejabat negara. Begitu juga tindakan terjadi dalam non akademik dan akademik. Selanjutnya penyimpangan perilaku secara moral tidak hanya dilakukan oleh orang dewasa. Anak-anak yang berada pada usia sekolah di Indonesia, baik pada tingkat Sekolah Menengah Atas (SMA), Sekolah Menengah Pertama (SMP), dan Sekolah Dasar (SD) juga sering melakukan perilaku yang kurang atau tidak bermoral. Sepanjang awal tahun sampai akhir bulan oktober tahun 2013, Komisi Nasional Perlindungan Anak (Komnas Anak) telah mencatat ada sejumlah 2.792 kasus kriminalitas yang dilakukan oleh anak usia sekolah di Indonesia, dengan rincian sebagai berikut : 1) 1.424 kasus adalah kasus kekerasan, seperti pemerasan dan pencurian; 2) 229 kasus tawuran; 3) dan sisanya berupa kasus asusila, penggunaan minuman keras dan obat-obatan terlarang. ${ }^{3}$ Orang-orang yang telah melakukan kejahatan ini (tidak bermoral) akan dihukum penjara sesuai dengan Undang-undang berdasarkan dengan kesalahan mereka berapa lama mereka menjadi tahanan. Hal ini menurut penulis pelaku tersebut perlu dilakukan pembinaan moral yang sifatnya berupa praktek bukan sekedar penyampayan teoriteori dan bukan sekedar hukuman fisik. Maka dari itu diperlukanya diperlukannya tasawuf sebagai solusi mengatasi kerusakan moral.

\footnotetext{
${ }^{3}$ https://media.neliti.com/.../52810-ID-fenomena-kenakalan-remaja-dan-kriminalit.pd
} 
Suatu hal yang tampaknya penting ketika diwacanakan urgensi tasawuf dalam konteks pembinaan moral. Sebab, inti dari ajaran tasawuf pada dasarnya adalah ajaran tentang moral (akhlak). Rasulullah SAW sendiri diutus untuk menyempurnakan akhlak yang mulia. ${ }^{4}$ Demikian pula semangat al-Qur'an sebagai sumber pokok ajaran Islam, menurut Fazlur Rahman, tema inti dan utamanya adalah semangat moral. ${ }^{5}$ Itulah sebabnya, akhlak Rasulullah SAW, menurut Aisyah, adalah al-Qur’an. ${ }^{6}$

Karenanya, urgensi tasawuf sebagai resulosi moral bangsa menjadi sangat penting, ketika kita melihat fakta dan realita, bahwa masyarakat yang beragama sekalipun ternyata tidak dijamin memiliki moralitas yang baik. Bangsa Indonesia adalah bangsa yang beragama, dan mayoritas bangsa Indonesia adalah beragama Islam. Tetapi kenyataannya, berbagai kerusuhan, pelanggaran hak azasi manusia, tindak korupsi, kolusi, suap, prostitusi, miras dan penyalahgunaan obat-obatan terlarang, perampokan, pembegalan, pencurian, dan tindak kriminal lainnya, hampir setiap hari terjadi di mana-mana mengisi lembaran dan mewarnai pemberitaan di berbagai media massa.

\section{B. Keadaan Moral di Indonesia}

Indonesia merupakan negara terluas di Asia Tenggara dengan jumlah penduduk terpadat di dunia. Kepadatan penduduk yang tidak seimbang akan membawa kesulitan dalam berbagai hal secara berkaitan, seperti penyediaan tempat tinggal, pendidikan, kesehatan, penyediaan lapangan pekerjaan, air bersih, dan lainlain. ${ }^{7}$ Hal ini menjadikan setengah jumlah penduduknya Indonesia hidup dalam kemiskinan. ${ }^{8}$ Dengan permasalahan kemiskinan (ekonomi) dan ditambah dengan mahalnya bahan pokok, mengakibatkan timbulnya tindakan kejahatan, seperti pencurian, perampokan, Narkotika, pembunuhan dan sebagainya.

\footnotetext{
${ }^{4}$ Lihat: Hadis riwayat Muslim dan Ahmad dari Abi Hurairah.

${ }^{5}$ Fazlur Rahman, Islam, (Bandung: Pustaka, 1404 H-1984 M), h. 36.

${ }^{6}$ Lihat: Hadis riwayat Muslim dari Aisyah.
}

7 “JENDELA HUKUM" FAKULTAS HUKUM UNIJA. Volume I Nomor 1 April 2014 KEMISKINAN SEBAGAI SALAH SATU PENYEBAB TIMBULNYA TINDAK KEJAHATAN, Yayuk Sugiarti. Fakultas Hukum Universitas Wiraraja Sumenep.

${ }^{8}$ https://www.usaid.gov/sites/.../091013_Indonesia_CLEARED\%20(Indonesian).pdf 
Kerusakan moral tidak hanya terjadi pada masyarakat miskin, melainkan juga terjadi pada masyarakat ekonomi menengah atas dan juga para pejapat negara. Tindakan yang tidak bermoral yang terjadi pada pejabat pemerintahan salah satunya adalah korupsi, tindakan korupsi merupakan perbuatan yang bertentangan dengan nilai-nilai moralitas kehidupan bermasyarakat, berbangsa dan bernegara, karena korupsi berarti mengambil atau mengurangi sesuatu yang menjadi hak orang lain atau tidak menjalankan tugasnya sebagaimana yang dibebankan kepada dirinya, bahkan beban tugas itu dikurangi secara sengaja. Perbuatan itu pada hakikatnya merugikan hak orang lain, organisasi, pemerintahan juga kebanyakan rakyat suatu negara.

Baharudin Lopa mengutip pendapat dari David M.Chalmers menguraikan arti istilah Korupsi dalam berbagai bidang, yakni yang mencakup masalah penyuapan, yang berhubungan dengan manipulasi dibidang ekonomi, dan yang menyangkut bidang kepentingan umum. Kesimpulan ini diambil dari pernyataan "manipulasi dan keputusan mengenai keuangan yang membahayakan perekonomian sering dikategorikan perbuatan Korupsi. Istilah ini sering juga digunakan terhadap kesalahan ketetapan oleh pejabat yang menyangkut bidang perekonomian umum. Selanjutnya dikatakan, pembayaran terselubung dalam bentuk pemberian hadiah, ongkos adminitrasi, pelayanan, pemberian hadiah kepada sanak keluarga, pengaruh kedudukan sosial, atau hubungan apa saja yang merugikan kepentingan dan kesejahteraan umum, dengan atau tanpa pembayaran uang, biasanya dianggap sebagai perbuatan korupsi. ${ }^{9}$

Di Indonesia korupsi seolah-olah sudah merupakan hal yang biasa didengar, dilihat oleh masyarakat, dan anehnya para pelakunya itu tidak merasabersalah apalagi malu bahkan sampai bersumpah bahwa dirinya tidak melakukan korupsi.

\section{Resolusi Tasawuf}

Krisis moral yang melanda bangsa Indonesia adalah sebagai akibat dari krisis spiritual. Sebab keberagamaan bangsa Indonesia pada umumnya, khususnya umat Islam, lebih mementingkan agama dalam bentuknya yang formal daripada rasa

\footnotetext{
${ }^{9}$ Hartati, Evi, 2008, Tindak Pidana Korupsi, Jakarta, Sinar Grafika, hlm. 8.
} 
penghayatan batin terhadap agama, sehingga agama tidak menimbulkan kesan apaapa pada jiwa mereka. Penghayatan batin terhadap agama dapat ditempa melalui latihan rohani (riyâdhah) dan bersunggusungguhberjuang mengendalikan hawa nafsu (mujâhadah), dan tasawuf adalah sebagai salah satu solusi alternatif yang nanpaknya efektif dalam menumbuhkan rasa penghayatan batin terhadap pengamalan agama.

Adapun resolusi moral menurut tasawuf secara metodologis dapat dijelaskan sebagai berikut:

\section{a. Takhalli}

Pengertian takhalli menurut HM. Amin Syukur adalah membersihkan diri dari sifat-sifat tercela, noda dan penyakit hati yang merusak. Sedangkan Mustafa Zahri merumuskan takhalli sebagai upaya mengosongkan diri dari segala sifat-sifat yang tercela. M. Hamdani Bakran al-Dzaky menjelaskan bahwa takhalli yaitu metode pengosongan diri dari jejak dosa terhadap Allah Swt dengan jalan melakukan tobat yang sesungguhnya (taubatan nasuhah). ${ }^{10}$

Ramayulis menjelaskan bahwa takhalli secara umum diartikan sebagai membersihkan diri dari sifat-sifat tercela, dari maksiat lahir dan maksiat batin, mengosongkan diri dari sifat-sifat ketergantungan terhadap kenikmatan dunia. Cara pencapaian takhalli adalah dengan cara menjauhkan diri dari kemaksiatan dalam segala bentuk dan berusaha melenyapkan dorongan hawa nafsu jahat. ${ }^{11}$ Dengan demikian kemaksiatan itu sendiri dibagi dua, yaitu maksiat lahir dan maksiat batin. Maksiat lahir adalah segala sifat tercela yang dikerjakan oleh anggota lahir, seperti tangan, mulut, mata, telinga dan lain sebagainya. Sedangakan maksiat batin adalah segala sifat tercela yang diperbuat oleh anggota batin, yaitu hati. Pada tahap takhalli ini, memerlukan keras agar mampu mengosongkan diri dari segala sifat tercela yang dapat mendatangkan kegelisahan pada jiwa.

Fase takhalli merupakan fase penyucian mental, jiwa, akal pikiran dan hati, sehingga menghasilkan moral (akhlâq) yang mulia dan terpuji. Metode takhalli ini secara teknis ada lima, yaitu (1) menyucikan yang najis, dengan melakukan istinjâ' menggunakan air atau tanah, (2) meyucikan yang kotor, dengan cara mandi atau

10 M. Hamdani Bakran al-Dzaky, Konseling dan Psikoterapi Islam Penerapan Metode Sufistik (Yogyakarta: Fajar Pustaka Baru, 2002), 259.

${ }^{11}$ Ramayulis, Pengantar Psikologi Agama (Jakarta: Kalam Mulia, 2002), 138. 
menyiram air ke seluruh tubuh dengan, (3) meyucikan yang bersih, dengan cara berwudhu dengan air dan debu dengan cara yang baik, teliti dan benar, (4) meyucikan yang suci atau fitrah dengan mendirikan shalât taubat untuk memohon ampun kepada-Nya, (5) meyucikan yang Maha Suci, dengan berdzikir dan mentauhid-kan Allah Swt dengan kalimat lâ ilâha illallâh. ${ }^{12}$

Metode pensucian ruhani ini adalah merenungkan keburukan di dunia dan menyadari bahwa dirinya adalah palsu dan cepat sirna dan mengosongkan hati darinya. Hal ini hanya dapat dicapai dengan melalui perjuangan menaklukan hawa nafsu dan kesungguhan perjuangan yang terpenting adalah melaksanakan peraturan-peraturan disiplin lahir secara terus menerus dalam keadaan apa pun. ${ }^{13}$

Nabi Muhammad Saw melakukan usaha mengasingkan diri dari dunia ramai ('uzlah) melakukan khalwat dan munâjat, menyepi diri agar mencari suatu esensi kebenaran. Nabi Saw mengambil tempat di Gua Hira' yang sepi dari keramaian, gelap gulita, berlokasi di sebelah utara kota Mekkah. Di tempat itu Nabi Saw merenung untuk mendapatkan kesucian akal dan ruhani, cahaya ketuhanan dan segudang petunjuk suci dari Allah Swt, sehingga dengan modal itu semua harapan untuk menyelamatkan umat dari kehancuran dan kebodo- han dapat terwujud.

Sebelum menjadi Rasul, Nabi Saw melakukan kegiatan 'uzlah dan khalwat sebagai aktivitas rutin setiap tahun, meninggalkan kota Mekkah dengan menyendiri untuk menghabiskan bulan Ramadhan. Jika bulan Ramadhan telah habis, Nabi Saw kembali lagi ke tengah-tengah masyarakat dan umat dengan bekal cahaya-cahaya ideologi dan kemantapan jiwa serta batin ilâhiyah, sebagai bekal taqarrub kepada Allah Swt. Kegiatan ini berlangsung seterusnya jika bulan Ramadhan tiba, Nabi Saw kembali menjalankan program pengembangan fitrah tauhid-nya sebagaimana tahuntahun yang lalu.

Hasil tempaan diri yang aktif dilakukan Nabi Saw secara terus menerus, disiplin dan total di dalam Gua Hira tersebut, benar-benar merupakan suatu keajaiban luar biasa. Nabi Saw memperoleh esensi ilmu dan pengetahuan tentang suatu kebenaran hakikat yang mampu mengantarkan manusia kepada jalan-jalan

${ }^{12}$ M. Hamdani Bakran al-Dzaky, Konseling dan Psikoterapi Islam, 259-260.

13 Ali ibn Ustman al-Hujwiri, Kasyf al-Mahjûb, terj. Suwardjo Muthary dan Abdul Hadi WM (Bandung: Mizan, 1992), 263. 
hidup dan kehidupan berarti. ${ }^{14}$ Setelah beulang-ulang sepanjang bulan Ramadhan hingga berusia 40 tahun, Nabi Saw akhirnya menerima cahayacahaya esensi kebenaran dan kebenaran esensi dengan sukses.

Sebagaimana telah dijelaskan di atas, takhalli yaitu membersihkan diri dari sifat-sifat tercela dan juga dari kotoran-kotoran atau penyakit hati yang rusak. Langkah pertama yang harus ditempuh adalah mengetahui dan menyadari betapa buruk sifat-sifat tercela dan kotoran-kotoran hati tersebut sehingga muncul kesadaran untuk memberantas dan menghindari. Jika hal ini bisa dilakukan dengan sukses, maka seseorang akan memperoleh kebahagiaan. Hal ini sebagaimana telah ditegaskan Allah Swt dalam QS. al-Syams: 8-9.

Sifat-sifat atau penyakit hati yang perlu diberantas sebagaimana diterangkan oleh HM. Amin Syukur meliputi tujuh hal. ${ }^{15}$ Pertama adalah sifat hasad, yang berarti iri dan dengki. Hal ini terkandung pengertian adanya keinginan hilangnya suatu nikmat dari tangan orang lain, agar berpindah kepada dirinya. Sifat ini dilarang oleh Allah Swt melalui QS. al-Nisa': 54 dan QS. al-Baqarah: 109.

Menurut Aboebakar Atjeh, hasad diartikan membenci nikmat Tuhan yang dianugerahkan kepada orang lain dengan keinginan agar nikmat orang lain itu terhapus. ${ }^{16}$ Hasad merupakan salah satu sifat jiwa yang keji, tidak dapt dihilangkan jika tidak memperoleh didikan dan latihan secara sufistik. Sebelum orang yang hasad itu mencapai maksud, lebih dahulu telah membinasakan diri dengan lima akibat, yaitu menderita duka cita yang berlarut-larut, menderita kecelakaan yang tidak dapat ditolong, memperoleh amarah Tuhan dan ditutup untuknya pintu hidâyah dan taufiq.

Meskipun demikian, terdapat sifat hasad yang tidak berarti dengki terhadap nikmat yang dikaruniakan kepada orang lain dan tidak juga menghendaki hilangnya karunia tersebut, namun sekadar mendorong cita-cita untuk berbuat sesuatu, sehingga memperoleh karunia seperti orang lain itu. Orang yang memiliki sifat ini termasuk sifat terpuji dan memperoleh pahala di hari akhirat. Sifat ini dinamakan munâfasah atau ghirah.

\footnotetext{
${ }^{14}$ M. Hamdani Bakran al-Dzaky, Pendidikan Ketuhanan Dalam Islam (Yogyakarta: tp, 1990), 42.

${ }^{15}$ HM. Amin Syukur, Pengantar Studi Islam, 228-234.

16 Aboebakar Atjeh, Pendidikan Sufi Sebuah Upaya Mendidik Akhlak Manusia (Solo: CV.Ramadhani,1991), 31-32.
} 
Imam al-Ghazali mengatakan bahwa hukum hasad itu haram, yaitu hasad yang memiliki tujuan menghilangkan sesuatu nikmat pada diri orang lain dan mengharapkan datang celaka kepada orang lain itu. Sedangkan munâfasah, yaitu keinginan agar memperoleh nikmat seperti orang lain itu dengan tidak menghendaki kebinasaan terhadap orang itu. Sifat ini menurut al-Ghazali tidak haram. Bersinonim dengan kata munâfasah, HM. Amin Syukur menegaskan ightibâth, yaitu keinginan untuk memperoleh nikmat seperti nikmat yang diperoleh orang lain seperti ilmu, harta kekayaan kedudukan dan kebaikan, tanpa adanya keinginan hilangnya nikmat itu dari orang tersebut. Hukum sifat ini adalah diperbolehkan. ${ }^{17}$

Namun bertolak belakang dengan hasad adalah sifat haqad, yaitu dengki yang sudah membuahkan permusuhan, kebencian dan memutuskan silaturrahim. Hal ini adalah sifat yang paling buruk dan sangat tercela. Menurut Nabi Saw, sifat ini besar sekali dosanya, karena orang yang demikian itu telah termasuk ke dalam golongan orang yang memisahkan diri dari sesama Islam dan membuka rahasia sesama saudara, sehingga baginya tidak ada tempat lain kecuali neraka.

Kedua adalah sifat al-hirshu. Kata al-hirshu didefinisikan sebagai suatu keinginan yang berlebih-lebihan terhadap masalah-masalah dunia. Sifat selalu ingin menang merupakan sifat manusiawi dan sifat pembawaan manusia, sebagaimana dijelaskan dalam QS. Ali Imran: 14. Islam memandang bahwa keinginan yang berlebih-lebihan adalah dilarang, namun keinginan dalam batas kewajaran dan untuk memenuhi kebutuhan primer seseorang, masih dalam batas diperbolehkan, karena merupakan sarana mempertahankan eksistensi di atas dunia ini, namun cara dan materi pemenuhan keinginan (kebutuhan hidup) itu dalam kerangka norma dan kaidah yang berlaku.

Ketiga adalah sifat al-takabbur. Kata al-takabbur diartikan kesombongan, yaitu sikap dan sifat merendahkan orang lain dan bisa berarti menolak kebenaran (alhaqq). Orang yang berlaku sombong (al-takabbur) didorong karena ada-nya perasaan kelebihan pada diri sendiri, seperti ilmu pengetahuan, amal ibadah, keturunan orang terhormat, harta kekayaan, kekuatan fisik, kedudukan, kecantikan, ketampanan dan lain sebagainya. ${ }^{18}$ Pada tahap realisasi, sifat ini dapat

\footnotetext{
${ }^{17}$ HM. Amin Syukur, Pengantar Studi Islam, 228-229.

${ }^{18}$ HM. Amin Syukur, Pengantar Studi Islam, 228-229.
} 
diklasifikasikan menjadi tiga macam, yaitu (1) al-takabbur kepada Allah Swt, seperti Fir'aun yang mengaku sebagai Tuhan, ini adalah al-takabbur yang terjelek, (2) altakabbur kepada rasul-Nya seperti orang-orang Quraisy, (3) al-takabbur kepada sesame manusia. Ketiga macam al-takabbur harus dihilangkan dari diri manusia.

Keempat adalah sifat al-ghadhab, yang berarti marah. Sifat ini merupakan pembawaan setiap manusia, namun mereka berbeda dalam kadar, ada yang berdarah dingin, berdarah panas dan ada yang berdarah sedang. Orang yang berdarah dingin tidak memiliki sifat marah atau jika memiliki, hanya kadar sedikit. Orang seperti ini dinilai tidak baik, karena justru manusia suatu ketika harus marah, ketika menyangkut hak asasi yang harus dipertahankan. Imam Syafi'i pernah menyatakan, barang siapa yang semestinya harus marah, akan tetapi tidak mau marah, maka orang itu sepeti keledai (himâr). Orang yang berdarah panas, sedikit tersinggung perasaannya, naik pitam, sehingga lupa daratan, keluar dari rel pemikiran yang sehat dan ketentuan agama, bahkan seperti orang gila. Marah pada awalnya seperti orang gila, tetapi akhirnya akan menyesal. Dalam hubungan ini, menurut HM. Amin Syukur, yang paling baik adalah bersikap tengah di antara keduanya, yaitu marah untuk membela suatu kebenaran (al-haqq), artinya marah yang proporsional.

Kelima adalah sifat al-riyâ' dan al-sum'ah. Sifat al-riyâ' berarti mencari simpati dengan mempertahankan kebaikannya. Sifat ini dilarang oleh Allah Swt dalam QS. al-Ma'un: 4-6.

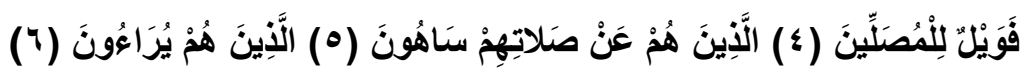

Artinya: Maka celakalah orang yang shalat, (yaitu) orang-orang yang lalai terhadap shalatnya yang berbuat riya.

Hal-hal atau kebaikan yang diperlihatkan meliputi tubuh, perhiasan, ucapan, amalan lahir, pengikut atau teman dan lain sebagainya. Tanda-tanda orang yang alriyâ' adalah malas beramal ketika berada dalam kesendirian dan giat jika dilihat orang banyak serta menambah amalnya ketika dipuji orang dan menguranginya ketika dicaci. Sifat al-sum'ah adalah sifat tercela yang mirip dengan al-riyâ'. Namun sifat al-sum'ah melakukan amal kebaikan disertai tujuan agar didengar oleh orang dengan tujuan ingin populer. 
Keenam adalah sifat al-'ujub atau al-ta'jûb. Sifat al-'ujub adalah mengherani diri sendiri atas kebaikan yang dilakukan dan kelebihan yang dimiliki tanpa mengingat pemberi dan pendukungnya. Sifat ini memiliki pengaruh negatif terhadap diri seseorang antara lain menjurus kepada sifat sombong (al-takabbur), lupa nikmat Allah Swt dan dosanya dan lain sebagainya. Dalam hal ini, Allah Swt sudah mencelanya dalam QS. al-Taubah: 25

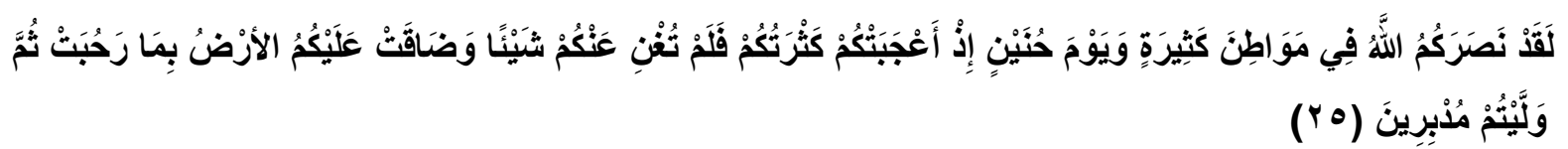

Artinya: Sungguh, Allah telah menolong kamu (mukminin) di banyak medan perang, dan (ingatlah) perang Hunain, ketika jumlahmu yang besar itu membanggakan kamu, tetapi (jumlah yang banyak itu) sama sekali tidak berguna bagimu, dan bumi yang luas itu terasa sempit bagimu, kemudian kamu berbalik ke belakang dan lari tunggang langgang.

Selanjutnya dalam QS. al-Kahfi: 104.

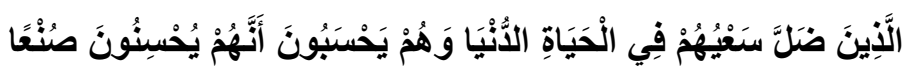

Artinya: Yaitu orang-orang yang telah sia-sia perbuatannya dalam kehidupan dunia ini, sedangkan mereka menyangka bahwa mereka berbuat sebaik-baiknya.

Ketujuh adalah sifat al-syirik. Sifat ini berarti mempersekutukan Allah Swt dengan makhluk-Nya, baik dalam dimensi rubûbiyah, mulkiyah maupun ilâhiyah, secara langsung atau tidak langsung, secara nyata atau terselubung. Dalam dimensi rubûbiyah, misalnya, meyakini bahwa ada makhluk yang mampu menolak segala kejelekan dan meraih segala kebaikan atau mampu memberikan berkat, seperti meyakini kesaktian para wali Allah Swt, sehingga minta bantuan kepada mereka untuk menolak petaka atau untuk meraih keuntungan, apalagi jika wali tersebut sudah meninggal dunia.

Dalam dimensi mulkiyah, misalnya, adalah mematuhi sepenuhnya para penguasa non-muslim, bukan karena terpaksa, di samping menyatakan patuh kepada Allah Swt, padahal pemimpin non-muslim itu menghalalkan yang diharamkan Allah Swt dan mengharamkan yang dihalalkan atau mengajaknya melakukan kemaksiatan. ${ }^{19}$ Dari tujuh sifat tersebut perlu dihindari dan dihilangkan dengan cara 2002), 70

${ }^{19}$ Yunahar Ilyas, Kuliah Aqidah Islam (Yogyakarta: Lembaga Pengkajian dan Pengamalan Islam, 
takalli serta melakukan rangkayan ritual mensucikan yang najis (istinjâ'), mandi, berwudu, sholat tobat, dan dzikir.

\section{b. Tahalli}

Menurut HM. Amin Syukur, tahalli adalah menghias diri dengan cara membiasakan sifat, sikap dan perbuatan yang baik. Sedangkan Mustafa Zahri

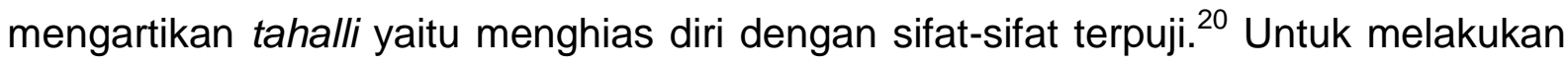
tahalli, langkahnya adalah membina pribadi, agar memiliki akhlâqul karimah dan selalu konsisten dengan langkah yang dirintis sebelumnya dalam takhalli. dengan melakukan latihan-latihan untuk membiasakan berprilaku baik akan menghasilkan manusia yang sempurna (insân kâmil).

Adapun langkah-langkah yang harus dilakukan yaitu kembali ke jalan yang benar (al-taubah), menjauhkan diri dari perbuatan tidak terpuji dan menanamkan sifat-sifat terpuji (mahmûdah) serta pengesaan Tuhan secara mutlak (al-tauhid), sikap hati mengambil jarak dengan dunia materi (al-zuhûd), cinta kepada Tuhan (alhubb), memelihara diri dari barang-barang yang haram dan syubhât (al-warâ'), tabah dan tahan dalam menghadapai segala situasi dan kondisi (al-shabru), merasa butuh kepada Tuhan (al-faqru), sikap terima kasih dengan menggunakan nikmat dan rahmat Allah Swt secara fungsional dan proporsional (al-syukru), rela terhadap segala yang telah diterimanya (al-ridhâ), berpasrah diri kepada Allah Swt setelah berusaha semaksimal mungkin (al-tawakkal), menerima pemberian Allah Swt secara ikhlas (al-qanâ'ah) dan lain sebagainya. Setelah seseorang berupaya melalui dua tahap tersebut, yaitu tahap takhalli dan tahalli, maka kemudian tahap ketiga yaitu tajalli.

\section{c. Tajalli}

Menurut Mustafa Zahri, tajalli adalah lenyapnya atau hilangnya hijâb dari sifatsifat manusiawi, jelasnya cahaya yang selama itu ghaib, lenyapnya segala yang lain ketika nampaknya wajah Allah Swt. ${ }^{21}$ Sedangkan Hasyim Muhammad menyatakan

\footnotetext{
${ }^{20}$ Mustafa Zahri, Kunci Memahami Ilmu Tasawuf, 82-89.

${ }^{21}$ Mustafa Zahri, Kunci Memahami Ilmu Tasawuf, 82-89.
} 
bahwa tajalli adalah lenyapnya sifat-sifat kemanusiaan yang digantikan dengan sifatsifat ketuhanan.

Menurut M. Hamdani Bakran al-Dzaky, tajalli adalah kelahiran atau munculnya eksistensi yang baru dari manusia, yaitu perbuatan, ucapan, sikap dan gerak-gerik yang baru, martabat dan status yang baru, sifat-sifat dan karakteristik yang baru, dan esensi diri yang baru. Itulah yang disebut dengan kemenangan dari Allah Swt. Telah lahirnya seseorang dari kelahiran yang baru dan di dalam hidup dan kehidupan yang baru adalah semata-mata karena pertolongan Allah Swt, syafâ'at Nabi Muhammad Saw dan doa para malaikat di sisi- Nya melalui upaya, perjuangan, pengorbanan dan kedisiplinan yang sangat tinggi dari diri sendiri dalam melaksanakan ibadah-ibadah berupa melaksanakan segala perintah-Nya, menjauhi larangan-Nya dan tabah terhadap ujian-Nya.

Hal ini bisa diketahui dari indikasi-indikasi yang muncul. Di antara indikasi kelahiran baru seorang manusia itu adalah pada tingkat dasar berupa kehadiran rasa aman, tenang dan tenteram, baik secara psikologis, spiritual maupun fisik, sebagai indikasi telah lenyapnya bekasan-bekasan hitam sebagai akibat dari pengingkaran atau maksiat kepada Allah Swt, yang melekat pada akal pikiran, hati, inderawi, jiwa, jasad dan kehidupan. Pada tingkat menengah adalah berupa kehadiran sifat, sikap dan perilaku yang baik, benar, sopan santun, tulus, istiqâmah, yakin, ksatria dan lain sebagainya secara otomatis, bukan rekayasa. Pada tingkat atas adalah berupa kehadiran potensi menerima mimpi yang benar, ilhâm yang benar dan kasyâf yang benar. Pada tingkat kesempurnaan adalah berupa kehadiran ketiga tingkatan itu ke dalam diri. ${ }^{22}$

Resulusi moral melalui tasawuf tampaknya lebih efektif daripada hanya sekedar doktrin ilmu akhlak yang bersifat teoritik, sehingga tasawuf diharapkan dapat mengatasi krisis spiritual dan krisis moral bangsa indonesia. Dengan tahapantahapan tersebut dapat diwujudkan dalam bentuk pendalaman ilmu, latihan rohani (riyadhah) dengan membiasakan melakukan kebaikan-kebaikan, dan memerangi hawa nafsu dengan sungguh-sungguh (mujahadah) untuk meninggalkan perbuatan maksiat.

\footnotetext{
${ }^{22}$ M. Hamdani Bakran al-Dzaky, Pendidikan Ketuhanan Dalam Islam, 328-329.
} 
Dengan demikian tasawuf menjadi solusi dan memberikan arah hidup kepada manusia khususnya pada pemimpin dan rakyat Indonesia agar mereka menjalin hubungan yang harmonis (ukhuwwah), menjalin hubungan tali kasih sayang (silaturahmi), menciptakan suasana damai (ishlâh) sehingga tidak terjadi ketidak adilan, kesenjangan sosial, peganiayaan dan pembunuhan. Dengan tasawuf sifat saling tolong menolong dalam kebaikan dan menjauhkan diri dari perbuatan melanggar hukum agama maupun hukum negara (ta'âwun 'ala al-birri wa altaqwâ), dermawan (sakha'), tolerensi (tasâmuh), rendah hati (tawadhu'). Serta mejadikan manusia tidak bersikap egois ("ujûb dan takabbur), tidak merendahkan orang lain (taskhir). Sehingga terbentuknya kepribadian yang bermoral.

\section{Penutup}

Pertama, melakukan tahapan takhalli (fase penyucian mental, jiwa, akal pikiran dan hati). Metode takhalli ini secara teknis ada lima, yaitu (1) mensucikan yang najis (istinjâ), mandi, berwudu, sholat tobat, dan dzikir. Kedua, melakukan tahapan tahalli. Menghias diri dengan cara membiasakan sifat, sikap dan perbuatan yang baik. Ketiga, tahapan tajalli. Pada tahapan ini lenyapnya sifat-sifat kemanusiaan yang digantikan dengan sifat-sifat ketuhanan. 


\section{DAFTAR PUSTAKA}

al-Dzaky, M. Hamdani Bakran, Konseling dan Psikoterapi Islam Penerapan Metode Sufistik (Yogyakarta: Fajar Pustaka Baru, 2002).

-------, Pendidikan Ketuhanan Dalam Islam (Yogyakarta: tp, 1990).

al-Hujwiri, Ali ibn Ustman, Kasyf al-Mahjûb, terj. Suwardjo Muthary dan Abdul Hadi WM, Bandung: Mizan, 1992.

Atjeh, Aboebakar, Pendidikan Sufi Sebuah Upaya Mendidik Akhlak Manusia (Solo: CV.Ramadhani,1991).

Hartati, Evi, 2008, Tindak Pidana Korupsi, Jakarta, Sinar Grafika.

llyas, Yunahar, Kuliah Aqidah Islam (Yogyakarta: Lembaga Pengkajian dan Pengamalan Islam, 2002)

Kurtines, William M. dan Jacob L. Gerwitz, Moralitas, Perilaku Moral, dan Perkembangan Moral, Jakarta: UI Press, 1992

Rahman, Fazlur, Islam, (Bandung: Pustaka, 1404 H-1984 M).

Ramayulis, Pengantar Psikologi Agama (Jakarta: Kalam Mulia, 2002)

Sugiartl, Yayuk, "Jendela Hukum" Fakultas Hukum. Volume I Nomor 1 April 2014, Kemiskinan Sebagai Salah Satu Penyebab Timbulnya Tindak Kejahatan, Fakultas Hukum Universitas Wiraraja Sumenep.

https://media.neliti.com/.../52810-ID-fenomena-kenakalan-remaja-dan kriminalit.pd https://www.usaid.gov/sites/.../091013_Indonesia_CLEARED\%20 (Indonesian).pdf 